\title{
Is it the soul of a new/lost machine?
}

\author{
Article
}

Published Version

Soga, L. R. (2016) Is it the soul of a new/lost machine? International Journal of Actor-Network Theory and Technological Innovation, 8 (2). pp. 18-31. ISSN 1942-535X doi: https://doi.org/10.4018/IJANTTI.2016040102 Available at https://centaur.reading.ac.uk/86581/

It is advisable to refer to the publisher's version if you intend to cite from the work. See Guidance on citing.

Published version at: http://dx.doi.org/10.4018/IJANTTI.2016040102

To link to this article DOI: http://dx.doi.org/10.4018/IJANTTI.2016040102

Publisher: IGI Global

All outputs in CentAUR are protected by Intellectual Property Rights law, including copyright law. Copyright and IPR is retained by the creators or other copyright holders. Terms and conditions for use of this material are defined in the End User Agreement.

\section{www.reading.ac.uk/centaur}

\section{CentAUR}

Central Archive at the University of Reading

Reading's research outputs online 


\title{
Is it The Soul of a New/Lost Machine?
}

Lebene Richmond Soga, Henley Business School, University of Reading, Reading, UK

\begin{abstract}
This paper is a throwback to The Soul of a New Machine by Tracy Kidder (Kidder, 1981b). Bruno Latour (1987), upon examining Tracy Kidder's story, observes that the heroic tale of engineers who worked on Eagle, a 32-bit minicomputer, was actually inspired by a machine! Over the years, however, this Latourian viewpoint seems to have been ignored. This paper thus examines how Kidder's story was received over the past three decades by the academic and non-academic communities. It exposes how various reviews of the story reinforce one's assumptions about how one approaches narratives about technology. A total of 228 reviews/analyses/commentaries about the story were analysed in a qualitative undertaking that also led the enquiry into a detailed analyses of the story's historico-cultural agency. The findings indicate that non-academic reviews focused largely on heroism, whereas in the academy, the story was approached in light of the prevailing academic discourses in management theory per any given decade of the book's journey; the story then became The Soul of a Lost Machine!
\end{abstract}

\section{KEYWORDS}

Bruno Latour, Technology, Tracy Kidder, Soul of a Lost Machine, Soul of a New Machine

\section{INTRODUCTION}

The relationship between humans and technology has long been a thing of interest to philosophy and the humanities. This interest not only remains in the abstract but also finds its existential outworking in society. In the academy, we continue to struggle with our conceptualisation of technology and its role in the social; this is evident in the ever increasing debates surrounding technological determinism (Marx \& Smith, 1994), the social shaping of technology (MacKenzie \& Wajcman, 1999), the social construction of technology (Pinch \& Bijker, 1987) and so on. While we grapple with these concepts, we also observe certain belief states about individuals who deploy technology. I define a belief state as a momentary (non)acceptance of a 'truth' state of events until a counterfactual position opens up a new way of thinking about that same 'truth' state. One example of this phenomenon can be found in the portrayal of Tracy Kidder's The Soul of a New Machine. That is, how have society, academia, and reviewers-journalists-subject matter 'experts'-public intellectuals-commentators (who make up the punditocracy) shaped an understanding of Kidder's 1981 Pulitzer award-winning story?

In this paper, an analysis of academic reviews, non-academic reviews and newspaper commentaries about Tracy Kidder's The Soul of a New Machine over the past three decades (that is, from 1981 to 2013), is made. The aim is not to quantitatively analyse what was said over the period, but to qualitatively examine how the story was received in both academic and non-academic circles, as well as the discursive resources that are drawn upon in light of the prevailing cultural and academic ideas of the 1980s. A two-fold mission is thus taken for this study: First, to examine the cultural reception of the story from the 1980s into the millennium. Second, to assess the academic treatment of the story vis-à-vis a Latourian approach that it was not so much about the human engineers in the story as it was the machine. 


\section{HOMO SAPIENS AND HOMO FABULANS}

Humans 'are born, bred, live and die within a great sea of stories' (Szabo, 2013, p. 6) and this fundamental human need demands that they assess, first, what stories they feed on, and second, how they feed on them. This is because narratives intricately weave our weltanschauung which then forms basis for individual and collective action. Schiffrin, De Fina, \& Nylund (2010) for instance argue that 'narratives are fundamental to our lives. We dream, plan, complain, endorse, entertain, teach, learn, and reminisce by telling stories. They provide hopes, enhance or mitigate disappointments, challenge or support moral order, and test out theories of the world at both personal and communal levels' (p.1). Additionally, it is important an examination is made of how stories are related to by Homo sapiens because their very nature as social animals make stories part of the thread that holds their communities together and in some cases, gives them a social identity. On the flip side, individualism suggests that 'basic narratives', as Czarniawska (1998) argues, 'can carry a load of ambiguity and therefore leave openings for negotiation of meaning' (Czarniawska, 1998, p. 3), the advantage being a weakening of any hegemony of the narrative (Boje, 2001) where a one-voiced omniscient narrator is behind every line.

Nonetheless, because humans are also Homo fabulans - makers and tellers of stories - a challenge to their understanding of narratives as they make and (re)tell is created. First, in making a story, the Homo fabulans risks neglecting some hidden aspects of the narrative. Ricoeur's argument here is instructive: 'A story describes a sequence of actions and experiences done or undergone by a certain number of people, whether real or imaginary. These people are presented either in situations that change or as reacting to such change. In turn, these changes reveal hidden aspects of the situation and the people involved, and engender a new predicament which calls for thought, action, or both' (Ricoeur, 1984, p. 150). Second, in (re)telling a story, the Homo fabulans risks presenting a narrative that fits existing weltanschauung (worldview), or a make-belief, or inadvertent omissions or distortions which may be attributed to the complex nature of the events that generated the story. This is particularly so when we consider that narratives are usually outcomes of 'complicated, prolonged, and ambiguous social, economic, and political interactions by many persons' (Cooper, 2003, p. 84) although other reasons are possible. For instance, narratives can also be outcomes of single-laned interpretations of what is believed to be of social relevance. Czarniawska (1998), in criticising our attempt to become modern, cites literature on collective memory in non-literate societies asserting that "what continues to be of social relevance is stored in the memory while the rest is usually forgotten' (Czarniawska, 1998, p. 9 Here, she cites Goody and Watt (1968).) In other instances, narratives could be a result of availability bias - that is, 'unwarranted importance to memories that are most vivid and hence most available for retrieval' (Mlodinow, 2008, p. 28).

Notwithstanding, it is agreeable to say that stories have some 'truth' to teach the human and the case to rename the Homo sapiens a Homo fabulans is worth a thought (Currie, 1998). The English have a saying that there's no smoke without fire and therefore 'truth' (the fire) can almost always be located at the base of stories (the smoke). Cooper informs us that stories 'tell us truths about basic human experience' (Cooper, 2003, p. 85) and for a story like Kidder's The Soul of a New Machine, Moon's words hold true that it 'has much to offer scholars beyond the pleasures of a story well told' (Moon, 2004, p. 601). This is because 'stories like these do more than merely entertain or divert us. Like ancient myths that captured and contained an essential truth, they shape how we see and understand our lives, how we make sense of our experience. Stories can mobilize us to action and affect our behaviour - more powerfully than simple and straightforward information ever can' (Reich, 1987, p. 77). 


\section{THE SOUL OF A NEW MACHINE}

As a backdrop to this paper, I attempt a brief overview of Tracy Kidder's book in as far off my critical stance as possible to only present just what Kidder himself wanted it to be - that is, a good story (Peters, 2002, p. 47). Kidder, an American literary journalist, had spent nearly two years at Data General, an American computer firm that separated itself from the mother company, DEC. Both companies would now compete with IBM's mainframe series - the minicomputers that were a new technological innovation with high market demand. However, Data General, which was one of the market leaders with its 16-bit minicomputer, could potentially lose ground to DEC, which had just released a 32-bit minicomputer called VAX. Kidder narrates how Tom West, a computer engineer at Data General manoeuvred through internal organisational politics in order to build a 32-bit minicomputer which was codenamed 'Eagle'.

Data General's internal politics were somehow revealed in the tensions that existed between two project teams, a privileged North Carolina team and Tom West's amateurish project team, which he formed by recruiting young graduate engineer rookies. With that, Kidder details the tension between these two engineering project teams as they both compete to build their own machines. As the story unfolds, the reader cannot help but admire how Kidder carefully details the toil, frustration, pain, and eventual achievement of Tom West and his rookie engineers in delivering the 32-bit 'Eagle' minicomputer. Suzanne Moon for instance realises how it is 'easy to get caught up in the drama and root for the team [i.e. Tom West's team] to come through' (Moon, 2004, p. 598). For McLaughlin, the reader can easily become mesmerised in relishing 'the romance of having accomplished the impossible' (McLaughlin, 1982, p. 62). As the story ends, the reader is potentially left applauding the heroic determination of Tom West and his team even though 'Eagle' was still too late to beat the competition of DEC's VAX machine. For Latour (1987), it was DEC's VAX machine that stimulated Tom West, a human, to action; it was VAX's agency that drove the entire story, but how did others receive the story?

\section{A HERO'S WORLD}

Soon after its publication, Bjørner (1981) evaluates The Soul of a New Machine as ascribing characters therein with 'almost transcendental qualities' (Bjørner, 1981, p. 1558). For Bjørner, Kidder's book is only a narrative of the triumph of men with extraordinary drive and impetus enabling them to overcome difficult challenges in their technological innovation. Kidder himself in a sequel also appraises actors in the book as the hardy boys (those who designed the circuitry) and the microkids (those who wrote the microcode of the machine) who beyond all conventions prove themselves as mavericks to 'rescue' their organisation (Kidder, 1981). McLaughlin (1982) then follows a similar review of The Soul of a New Machine by comparing it to Tom Wolfe's 1979 story, The Right Stuff in which Wolfe hyperbolically profiles the first astronauts in heroic technological work akin to Kidder's paean to Tom West and his team of young engineers in their technological innovation. He appraises Kidder's story as a creation of 'a mythos around an almost larger-than-life figure' (McLaughlin, 1982, p. 61) arguing that The Soul of a New Machine 'is not an exposé of the inner life of a hightech corporation. [Rather] it is an inspiring and much-needed antidote to those who claim there is no longer any work worth doing' (McLaughlin, 1982, p. 62). Such stance to Kidder's story in its early years, as one about heroism without insight into the taken-for-granteds, was only to become more apparent in other reviews and analysis.

In later reviews, authors either only demonstrated the heroism of the human or totally ignored possibilities of The Soul of a New Machine offering some understanding into the agency of technology in organisational life and management. For instance, Grier (2003), who posits what he calls 'great machine theory', identifies how Kidder dismisses conventional ideas about management in organisations. He quotes Kidder as asserting that it rather 'seems more accurate to say that a group 
of engineers got excited about building a computer' (Grier 2003, 96). Grier then suggests the story is a heroic one in which Kidder misses no words in praising the characters. That is, it is a story made of heroes and villains, take away their profiles and it ceases to be a fascinating story.

\section{OBTAINING THE DATA}

In exploring our assumptions about technological narratives like that of The Soul of a New Machine as well as the scholarly posture of the academy towards a story of this kind, the search for data needed a broad range of sources. Apart from Kidder's book itself, databases searched included EBSCO Host, Business Source Premier, ProQuest, JSTOR, ScienceDirect, ACM, IEEE Explore, Web Of Science, Google Scholar, Lexis-Nexis Database, New York Times Book Reviews, Goodreads reviews, and the popular Google's search. With search terms as 'Tracy Kidder', 'The Soul of a New Machine', 'American culture', 'Tom West', the study explored both academic and non-academic sources while sorting out outputs per relevance in order to stay within the aims of the investigation. Generally, sorting of the data was limited to the period between 1981 when the book was published, and 2013 when access to all the databases were made available to the researcher. This was a qualitative undertaking with verbatim quotes used in the analysis to express the direct intentions of their authors and to justify the analytic evaluations made by the researcher (Corden \& Sainsbury, 2005).

\section{TRACY KIDDER OR TECHIE KIDDER?}

One of the things that strike a reader of The Soul of a New Machine is the detailed technical description of computing and computer components by the author. It feels strange that a 'good story' that Kidder himself attests to as just what he was looking for in his year-long stay at Data General suddenly feels at some point like an educational material about computing. Bjørner for instance acknowledges in her review of the book, that its 'technical descriptions are lengthy' (Bjørner, 1981, p. 1558). Johnston (1982) also recognises this detail of the technical in Kidder's story by stating 'the narrative is also an interesting layman's introduction to how the architecture of a computer system is developed, and the current 'state of the art' in powerful minicomputers. It explains how the several levels of machine language interact, and are designed and perfected during the development programme of the project' (Johnston, 1982, p. 193). Elsewhere, the "'Soul of A New Machine'" described the workings of a computer' (United Press Int., 1987).

However, it is still worth noting that these technical details only serve to fulfil an objective but not to overwhelm the reader per se; but to what purpose then? Dorn absolves Kidder on this front, suggesting that 'Kidder is too good a writer to overwhelm a reader with minuscule detail' (Dorn, 1982, p. 190). Therefore, being that good a writer means that some resources are mobilised to make the reader believe the story. Moreover, in questioning this inclusion of so much technical detail, we are drawn to the work of Kahneman, Slovic, \& Tversky (1982) who observe that adding details to a story increases a story's credibility, particularly if those details tend to confirm our assumptions of the phenomenon. Accordingly, having been offered details of this kind, which a reader would otherwise not even need, The Soul of a New Machine is offered as a story about technological innovation indeed, and the reader is drawn to embrace its credibility. Kidder himself had stated elsewhere that 'I think that the nonfiction writer's fundamental job is to make what is true believable' (Kidder, 1994).

\section{HOW ABOUT THE PUNDITS?}

The Soul of a New Machine received (and still has maybe?) a great deal of attention from reviewers, journalists, subject matter 'experts', public intellectuals and commentators who took the story with delight and painted a heroic imagery that is common to great stories. However, such imagery turns 
out as a simulacrum, which stems from utopia in an order that may or may not be representative of reality (Baudrillard, 1994). Roland Barthes discusses such imagery as a representation of reality or a form of analogical perfection that carries two messages (Barthes 1977): a denoted message, which lays claim to representing what is real, and a connoted message, "which is the manner in which the society to a certain extent communicates what it thinks of it' (Barthes, 1977, p. 17). In other words, these representations become 'vehicles of communication' that are "intended" to transmit a concept' (Panofsky, 1955, p. 12) which in this case is that of heroism served in embellished words as seen in conversations about a story.

Shortly after its release, The Associated Press (1981) comments, 'Tracy Kidder's book, "The Soul of a New Machine," is the story of the people at Data General Corp. who put up with grueling deadlines and 70-hour workweeks to be part of Eagle, codename for the project.' This attribution of strength and endurance to characters in the story is then echoed in The New York Times (1982) telling us how Kidder details 'the personal rivalries, nearly obsessive drive to overcome engineering problems and Herculean team effort involved when a group of engineers, led by Mr. West, designed a computer' (Lueck, 1982). For Enright (1982), Kidder 'advises us to remember that the computer is a machine, and that it took human beings smarter than the computer to build and perfect it. The Soul of a New Machine, an enthralling account of how one machine was made, is to computer engineers what The Right Stuff was to astronauts - a story about men in groups who energize their imaginations toward a single goal, while striving to retain their individual quirkiness.' Later in The Globe and Mail (1982), we are told an 'effort to mythologize the inherently prosaic processes of corporationland occurs in Tracy Kidder's The Soul of a New Machine, in which a computer engineering executive named Tom West looms as heroic as any knight of the round table or titan of the fast draw. ...Computers have gone from being the inhuman villainous contrivances of the past, as exemplified by the HAL of 2001, to the infinitely fascinating creatures represented by video games and in such movies as Tron' (The Globe and Mail, 1982).

In its early years, commentaries on Kidder's story saw the emergence of a hero or a team of heroes maybe. They either wrote about it plainly or used analogies to express such heroism. In the case of the former, Bartimo reports, 'Kidder painted a picture of West as the sometimes charming, sometimes brooding older brother in a group of harred young engineers racing the clock against arch rival Digital Equipment Corporation (DEC)' (Bartimo, 1984). Here, West stands tall whereas in the latter, The Washington Post (1986) analogised the story as being like the building of a house by a family; the struggle of the husband, wife, architect and other workers till they finally finish the work. Similarly, Rodgers comments, "what was memorialized was the team and the grueling challenge they worked together to meet. ... it often reads like a mystery. The real heart — and soul — of the story is not the machine, but the people and their relationships'.

However, in an insightful twist that drifted from the ongoing popular heroic paean, Florman in The New York Times (1997) admits Kidder's story is about a display of heroism but is also quick to mention that the story is a response to an era in which some have mocked American innovation as being on the wane (Florman, 1997). This insight is taken further in Moon (2004) whose academic lens (understandably placing her outside the punditocracy) also refers to the historical/cultural epoch of the story as possibly informing Kidder's heroic presentation of characters. Indeed, technological innovation is intricately connected with its historical and cultural agency (Robins \& Webster, 1999). Therefore, stories like The Soul of a New Machine that make us see technological innovation as shaping the nature of work, without considering how the story itself was constructed may limit our understanding. Accordingly, it becomes paradoxical if we place more value on Kidder's story without equally considering the time within which it was written (see Huxley, 1963). Therefore, asking how the time of the story's conception influence or shape its formation helps us in the inquiry. 


\section{THE HISTORICITY}

In a review of The Soul of a New Machine,Dorn (1982), argues 'it is hard to find anything to criticize in the book, except that most readers would want more' (p.190) but as argued earlier, its historicocultural era requires a critical lens. Florman (1997) highlights that 'in microcosm the Eagle team exhibits the intensity and high spirits that pontifical social commentators keep saying Americans have lost.' In other words, Kidder has shown that West's Eagle team demonstrates to the reader that the American is still able to achieve the impossible, a counter to a prevailing notion of lameness in American productivity in that era. Kidder had spent nearly two years (from late 1978 to early 1980s) in Data General with the team to finally publish the story in 1981 (Peters 2002). The previous decade through to the year of publication of the story was considered an era in which American technological innovation and productivity were believed to have been on the decline (Silk 1983). Reasons for the declining productivity in American industry were ascribed to increasing external pressures particularly from Japan out of which many a technological innovation was surpassing American gadgetry. As such, many organisations began a struggle to change internal ways of working in order to keep up with the competition from Japan. Guest (1990) for instance makes reference to a major publication in Newsweek in 1981 that highlighted demands for increased productivity as a result of foreign competition. He reports that 'between 1979 and 1983, 44 per cent of employers had introduced some sort of employee involvement programme to increase productivity' (Guest, 1990, p. 385).

Additionally, calls for increased productivity and innovation in American industry were not only to be heard from social and political pundits but also from the academy as Guest has so well enumerated from many studies in his paper. The height of this era as he describes, culminated in Harvard Business School introducing Human Resource Management (HRM) in 1980 as a compulsory new course for its MBA programme. HRM was now seen as providing solutions to organisations by incentivising employees to increase productivity. Nonetheless, Guest avers, the underlying idea of HRM only represented 'persisting themes in the American dream' (Guest 1990, p.390). The American dream carried powerful notions of America as a land of opportunity for which any individual through hard work (as seen in Tom West and his engineers in The Soul of a New Machine), could achieve success beyond imagination without giving in to the envy of another (Nohria, 2013), in this case, Japan. The pride was that, 'the solutions to Japanese competition can be found in America's own backyard, in getting back to basics' (Guest, 1990, p. 391). Tom West and his Eagle team thus represented this pride. For Kidder, these characters showcased the American as still able to innovate or achieve the seemingly impossible. Arguably, the drab of the preceding years would make Kidder rise to the challenge of denouncing the pale commentary of a lack of innovation in America. For instance, Apple Computer launches its first product in April 1976, Star Wars debuts in cinemas in 1977 with the phrase, 'may the force be with you' (Batchelor, 2009), and Tom Wolfe names the decade 'The 'Me' Decade and The Third Great Awakening' (Batchelor 2009) and then publishes his classic The Right Stuff in 1979 inter alia. Nonetheless, the fact that Japan was now a major threat to America in terms of technological innovation remained clear; Japanese products, which were mocked in the 1930s as being low quality, had now become a major competition. Example, the first stand-alone Betamax video cassette recorders (VCR) is launched in 1976, the first coin-operated video game Space Invaders - is released in Japan in 1978 and is later brought to America, the Sony Walkman is also introduced in Japan in 1979 and by the 1980s, 'the Japanese electronic industry was arguably at the height of its dominance' (Hays, 2009, n.p).

However, the 1980s in America, which was now the 'Me' decade, became an era where status and exhibitionism were prominent. For instance, 'Forbes' list of 400 richest people became more important than its 500 largest companies. Binge buying, 'Shop Til you Drop' was the watchword. Labels were everything, ... Video games, aerobics, minivans, camcorders, and talk shows became part of our lives' (Whitley, 1999, n.p). America was literally immersed in consumerism without commensurate productivity. Furthermore, a study by UCLA and American Council on Education in 1980 indicated that 'college freshmen were more interested in status, power, and money than at any time during the past 15 years' (Whitley, 1999). Additionally, fiction authors (e.g. Ken Follet, Tom 
Clancy, Robert Ludlum, and so on) became popular, and literary art, which took a 'push toward new journalism, a genre of nonfiction that incorporated elements of fiction, continued through the first half of the decade' (Batchelor, 2009, p.163) and became a major form of communication particularly in books and magazines (e.g. Ms., Hustler, People, and New York Magazine). Certainly, that genre of writing can also be said to be characteristic of Kidder's story. With such display of extravagance in that cultural era, Guest (1990), Florman (1997) and Moon (2004) indicate how calls were made for increased productivity in American organisations. Kidder therefore steps up with The Soul of a New Machine depicting that all is not lost for American innovation; the American is still able to harness what it takes to achieve great feats. Kidder himself observes of his story that,

for some writers lately the job has clearly become more varied: to make believable what the writer thinks is true (if the writer wants to be scrupulous); to make believable what the writer wishes were true (if the writer isn't interested in scrupulosity); or to make believable what the writer thinks might be true (if the writer couldn't get the story and had to make it up) (Kidder, 1994, p.14).

As a result, Kidder makes believable that America, despite its epoch of indulgence, could still innovate even under impossible conditions.

\section{HOW ABOUT THE ACADEME?}

Foltman, in the National Productivity Review (1981) describes the story's human characters as a team of engineers who managed to do the impossible despite internal organisational tensions and contradictions (Foltman, 1981). A year later, in the Financial Analysts Journal, Cummin (1982) evaluates Kidder's story as an analysis of the enormous tension individuals had to work under to eventually gain a final victory. The author then argues how the story shows a management style that was almost synonymous with abandonment of employees who still achieved their expected result. For Dorn (1982) in Annals of the History of Computing, Tom West and his team of youthful engineers dismissed the conventional management style to achieve the impossible; 'It is sometimes hard to grasp, emotionally and intellectually, that the people Kidder writes about are real' (Dorn, 1982, p. 189). Johnston (1982) in Electronics and Power would rather see Kidder's story as a fascinating interplay of technical concepts and management ideas as individuals set out to build a machine in a complex environment. Ultimately as Ives (1982) notes, the story is simply a group of young engineers performing a heroic task.

Nonetheless, in Journal Of The American Society For Information Science (1982), Meadow, who reviews the story as a fascinating account of technological innovation, 'a story of people anywhere, under pressure' (Meadow, 1982, p. 349) and one that challenges the reader to do the impossible, also highlights it as a story that humanises technologists. In other words, characters are not just supermen but also represent 'normal' employees. Explained in Feerst (1982), characters may have demonstrated heroism but they are also villains being 'inexperienced rookies who are led, manipulated, and ultimately screwed by Data General's corporate structure' (p.84). Willet (1983) then adds, these young engineers are rookies and victims who are exploited by Data General. In the Journal of American Studies (1983), however, Brucher brings back the strength of Americanism describing the story as one of 'men and women who refuse to be defeated by machines' (Brucher, 1983, p. 327), the machine being 'a worthy adversary for adventurous spirits' (ibid, p. 333). At least, here, the machine is ascribed some human characteristic but it ends there. In the academy, the portrayal of pure heroism by characters gets attributed either to an abandonment of prevailing management styles, or an outcome of draconian management techniques as Tromer (1997) puts it, or a conquest over technology by the human. Additionally, the academic lenses also implicitly appreciate the work of a human collective rather than the heroic efforts of one individual. Ward (1984) for instance narrates the story as the 'recruitment and formation of ....[a] development team, their personalities, ...trials, ...politics, ....egos, 
...frustrations, ...disappointments, ...' (Ward, 1984, p. 114) but who finally achieve their goal. For Reich in the Harvard Business Review (1987), it is not so much about Tom West as it is about a team that performed the heroic. The effort of the whole, he argues, 'is greater than the sum of individual contributions' (Reich, 1987, p. 78).

Although academic interest in The Soul of a New Machine in the 1990s seemed low, the millennium saw a resurgence of academic curiosity in the story. Shipp (2002) in Academy of Management Executive reckons the story was irresistibly attractive because of the writing, its focus on people, its avoidance of a narrow prescriptive approach to management, and the fortunate timing (as a necessary deviation from conventional management books of that era). It had much to offer scholars 'beyond the pleasures of a story well told' (Moon, 2004, p. 601). Forbes \& Domm (2004) then identify 'intrinsic motivation' as what got characters in the story to achieve the impossible, not just a tale of heroism. Later, others reasoned that the story remained a mirror of corporate project management life in the millennium and therefore revisited it (Levy, 2008; Price, 2010). Overall, the academy's critical stance shifted reviews from the heroic to critique on prescriptive management practices to teamwork to relevance in present day corporate project management.

So far, two insights emerge in the analysis. First, it seems that the cultural zeitgeist could not be decoupled from Kidder's story about technological innovation. Second, it appears the dominant academic management theories of the decades stand closely linked to the position of the academe. For instance, in the 1980s academic reviews critique the heroic presentation of only Tom West; importance is given to teamwork instead of individual actions although lessons from individual actions are recognised in some cases. Over the same period, major management academic discourses centred around corporate culture, (See Deal \& Kennedy, 1982) Japanization (Pascale \& Athos 1981), personnel and human resource management (Guest 1987). For the next decade in the 1990s, not many academic reviews of the book are available presuming that interest in the book was low; reasons for this are not clear and are beyond the scope of this enquiry. However, Tromer's (1997) review critiques Kidder's heroic presentation of the engineers and also argues the story is a tale of draconian management activity. In that decade, major academic management discourses centred on collaborative learning, (See Lave \& Wenger, 1991) organisational collaboration/learning, (Gibbons et al., 1994; Senge, 1990), knowledge management (Nonaka \& Takeuchi, 1995) and business process reengineering (Hammer \& Champy, 1993). In the millennium where academic interest in The Soul of the New Machine seems to resurge, reviewers stress the relevance of the story to understanding individual motivations, corporate culture, and project management. In this decade, academic management discourse has seen a shift from the collective to the individual in Human Resource Management (See Watson, 2004), a continuation of organisational learning and knowledge management (knowledge as practice) (See Easterby-Smith \& Lyles, 2011) and projects, project management and project organisations (Turner 2009) inter alia.

Undoubtedly, there are many more academic management discourses over the past three decades but qualitatively, one could say that the academic reception of The Soul of a New Machine seems to be consistent with major discourses in management theory in the era of the reviews. Perhaps this may be an indication of how we tend to see through the lenses we collectively construct for ourselves (Mlodinow, 2008). Non-academic reviews on the other hand only seem to view the book in its original 'Kidderian' intention of a good story, that is, the heroic determination of Tom West and his team of engineers in accomplishing a great task. In all these, the machine is completely lost in the analyses!

\section{ON HEROISM}

The focus on heroism is evident in Grier's (2003) analysis of the story. He problematizes his great machine theory with the idea that great machines are still products of great people therefore in shifting our focus 'from the great person to the great machine to the great software package, we are [still] faced with the problems of heroes and heroic endeavors' (Grier, 2003, p. 97). He supports this argument with the words of hero worshipper Thomas Carlyle who in the midst of his lecture on heroes pauses to declare: 
This London City, with all its houses, palaces, steam-engines, cathedrals, and huge immeasurable traffic and tumult, what is it but a Thought, but millions of Thoughts made into One-a huge immeasurable Spirit of a THOUGHT, embodied in brick, in iron, smoke, dust, Palaces, Parliaments, Hackney Coaches, Katherine Docks, and the rest of it! Not a brick was made but some man had to think of the making of that brick (Grier 2003, p.97).

Moreover, Tromer (1997), who acknowledges Kidder's story as unbalanced in favour of the heroic, still argues that such presentation was crucial as a counterweight to the traditional drab image of characters involved in technological innovations of that kind. Heroic ascriptions have always occurred in literature. However, our clinch on personifying heroism in literature only makes us compensate for our lack of curiosity in asking further questions. For example, if the inquisitive child asked “"where did corn come from?" her elders didn't launch into an explanation of seed selection over thousands of years. "Corn came from the corn god," was the short and sufficient answer-as well as the opportunity for a good story'(Cooper, 2003, p. 82). This focus on only the heroic, even in some academic circles, without questioning how that came to be is also partly due to the author-reader contract (Czarniawska, 2004).

\section{KIDDER AND THE SOUL OF A ‘LOST’ MACHINE: A DISCUSSION}

A story defines a contract between its author and the reader. This contract, which is also a bridge constructed by the author, beckons the reader to journey into an unknown that has now been made known by the author. The reader who travels across that bridge implicitly enters this author-reader contract. According to Czarniawska (2004), it is a tacit contract in which the author appeals to the reader to suspend any disbelief while promising to please the reader on his or her journey across that bridge. In Kidder's story, the reader is almost certainly placed in a position to sign a contract to disregard technology or at best be ambivalent towards it. As is evident, many a reviewer, who only relishes the heroic work of the human offer little thought to the role of the machine. In Brucher's review as an example, it is 'a story of men and women who refuse to be defeated by machines' (Brucher, 1983, p. 327), the implication being, the human is pre-eminent and any attempt by the machine to overthrow it will be resisted; the machine must forever remain invisible. Kidder, through the text, has thus asked the reader to look beyond the machine, that is, to place it in a domain of losers even if it finds its way into man's existential struggles. This stance on technology was more explicitly stated two decades later when Kidder was interviewed. He taunts:

Another thing that I wonder about is technology. I remember distinctly, not too many years ago, being on an airplane on a businessman's flight mostly. Walking down the aisle back from the bathroom and looking over the shoulders, just about everybody had a laptop open. I swear, at least two-thirds were playing computer games. I don't know quite what to make of that. I think we tend to place this enormous faith in technology, misplaced faith. Not that It's not important. For a long time, I didn't work on a computer. People would say, "What kind of computer do you use?" It was still in the early '80s at this point, and they still weren't really all that great. I started to conceive a real hatred for them, because they just seemed so inflated to me. It was just another tool, for heaven's sakes! (Peters, 2002, p. 50).

As Boje (2001) rightly asserts, 'no story is ideologically neutral' (Boje, 2001, p. 18) and therefore one could argue that Kidder has through the text almost coerced or manipulated the reader to inhabit a world as he (that is, Kidder) saw it; a world in which machines were irrelevant or mere servants to humans who are its gods. A contrary notion is that; Kidder could not have coerced the reader into accepting his stance on technology. After all, he spends a significant amount of space in detailing the components and capabilities of the machine to the reader, a sign of its relevance and prominence 
in the story. Rather, the reader is left to decide whether the machine is indeed to be taken seriously or to be taken for granted in the story. Dorn for instance tells us:

A writer builds a picture in words for the reader. Each reader fleshes out the picture, creating a mental image of the appearance of characters and settings. That's enough. Here is the difference between radio and television. The great radio shows suggested; the details were left to the listener (Dorn, 1982, p. 190).

Nonetheless, Dorn's assertion above still problematizes the role of the author. This is because there are always alternative images that could have been painted in words by the author, yet s/he chooses to offer a preferred option. Thus, the author still has the prerogative to choose what picture in words to paint for the reader since the text becomes an obligatory point of passage for the reader if (s)he (that is, the reader) wishes to enter the world of the story. The story therefore legitimates a certain point of view among alternatives (Boje, 2001).

To this end, we can only take a Latourian posture in reckoning that the author, the text, and the reader all act on each other but all also have the choice among alternatives to offer an understanding desired by each. Furthermore, the author-text-reader relationship may be conceived of as a network of actors, perhaps a 'network of interpretants' as described by Eco, who argues that we live in a

universe of semiosis, that is, the universe of human culture, [which] must be conceived as structured like a labyrinth of the third type: (a) it is structured according to a network of interpretants; $(b)$ It is virtually infinite because it takes into account multiple interpretations; (c) It does not register only 'truths' but, rather, what has been said about the truth or what has been believed to be true (Eco Umberto cited in Rorty, 1992, p. 110).

From that point of view, Kidder, The Soul of a New [or rather a lost] Machine, and the reader become entangled in a triple labyrinth with each convoluted unit representing a complexity of ideas that arise from the production and exchange of meaning. According to Lehman, 'the emphasis in these sorts of readings is on the relationship of the writer to his subject and to his reader within a literary and social context' (Lehman, 1997, p. 42).

\section{CONCLUSION}

As set out for this study, revisiting stories about technological innovation like Kidder's The Soul of a New Machine not only brings new insights surrounding its context, it also reveals perhaps more than is evident what the reader has made of the story. In this paper, it was shown how Kidder's careful choice of technical detail reinforced the story as one that is indeed believable but which simultaneously presented the reader with a tale of heroism. In addition, this paper has thrown some light on the historico-cultural agency of Kidder's story that leaves its reader to relish the joy of true Americanism in an era of sheer material indulgence (the 'Me' decade). Whereas non-academic reviews of Kidder's story focused largely on the heroic, which resonates with the Kidderian presentation, in the academy however, we seemed to only see the story through our prevailing academic theoretical lenses. One implication is that, a reader will most likely consume what is on offer but the academic reader will filter to see what s/he wants to see because s/he will use the available academic lens to look through it. One exception in the academy, however, is the Latourian approach in which mention is made of the agency of a non-human actor in Kidder's story as deserving equal attention in any narrative of technological innovation (Latour, 1987). In effect, our historical analyses of technological innovation must, as a necessity, also pay attention to the taken-for-granteds in the narratives. It is not just what is there that is important; what is not said must be equally or even more thoroughly sought by the academic reader of such texts. 


\section{REFERENCES}

Barthes, R. (1977). Image, Music, Text (Essays selected and translated by Heath, S.). London: Harper Collins Publishers.

Bartimo, J. (1984). Tom West. InfoWorld.

Batchelor, B. (2009). American Pop: Popular Culture, Decade by Decade (Vol. 1,2,3,4). Westport, CT.: Greenwood Publishing Group.

Baudrillard, J. (1994). Simulacra and Simulation (S. F. Glaser, Trans.). Ann Arbor: University of Michigan Press. Bjørner, S. (1981). The Soul of a New Machine (Book). Library Journal, 106(14), 1558.

Boje, D. M. (2001). Narrative Methods for Organizational and Communication Research. London: Sage.

Brucher, R. (1983). Willy Loman and 'The Soul of a New Machine': Technology and the Common Man. Journal of American Studies, 17(3), 325-336. doi:10.1017/S0021875800017795

Cooper, C. C. (2003). Myth, rumor, and history: The Yankee whittling boy as hero and villain. Technology and Culture, 44(1), 82-96. doi:10.1353/tech.2003.0009

Corden, A., \& Sainsbury, R. (2005). Verbatim quotations: Whose views count? Qualitative Research, 1(1), 4-6.

Cummin, R. (1982). Book Reviews: The Soul of a New Machine. Financial Analysts Journal, 38(3), 10.

Currie, M. (1998). Postmodern Narrative Theory. London: Macmillan. doi:10.1007/978-1-349-26620-3

Czarniawska, B. (1998). A Narrative Approach to Organization Studies. London: Sage. doi:10.4135/9781412983235

Czarniawska, B. (2004). Narratives in Social Science Research: Introducing Qualitative Methods. London: Sage. doi:10.4135/9781849209502

Deal, T. E., \& Kennedy, A. A. (1982). Corporate Cultures: The Rites and Rituals of Corporate Life. Reading, MA: Addison-Wesley.

Dorn, P. (1982). Reviews: Kidder, Tracy. The Soul of a New Machine. Annals of the History of Computing, 4(2), 188-190. doi:10.1109/MAHC.1982.10019

Easterby-Smith, M., \& Lyles, M. A. (Eds.). (2011). Handbook of Organizational Learning and Knowledge Management. Sussex: Wiley.

Enright, M. (1982). The Soul of a New Machine. The Globe and Mail. Canada.

Feerst, I. (1982). The Wars of Computer Design (Book Review). Business and Society Review, 41.

Florman, S. C. (1997). The Hardy Boys And The MicroKids Make A Computer. The New York Times. Retrieved from http://www.nytimes.com/books/99/01/03/specials/kidder-soul.html

Foltman, F. (1981). Keeping Current/Books: Managing to do the 'impossible': The Soul of a New Machine. National Productivity Review, 1(1), 127-128. doi:10.1002/npr.4040010115

Forbes, J. B., \& Domm, D. (2004). Creativity and Productivity: Resolving the Conflict. SAM Advanced Management Journal, 69(2), 4-27.

Gibbons, M., Limoges, C., Nowotny, H., Schwartzman, S., Scott, P., \& Trow, M. (1994). The New Production Of Knowledge: The Dynamics Of Science And Research. In Contemporary Societies. London: SAGE.

Grier, D. A. (2003). The Great Machine Theory of History. IEEE Annals of the History of Computing, 25(3), 96-97. doi:10.1109/MAHC.2003.1226668

Guest, D. E. (1987). Human Resource Management And Industrial Relations. Journal of Management Studies, 24(5), 503-521. doi:10.1111/j.1467-6486.1987.tb00460.x

Guest, D. E. (1990). Human Resource Management And The American Dream. Journal of Management Studies, 27(4), 377-397. doi:10.1111/j.1467-6486.1990.tb00253.x 
Hammer, M. M., \& Champy, J. A. (1993). Reengineering the Corporation: A Manifesto for Business Revolution. New York: HarperCollinsPublishers.

Hays, J. (2009). Retrieved from http://factsanddetails.com/japan.php?itemid=922\&catid=24\&subcatid=157

Huxley, A. (1963). Literature and Science. New York: Harper and Row.

Ives, B. (1982). Review of 'The Soul of a New Machine, by Tracy Kidder'. ACM SIGMIS Database, 13(2-3), 46-47. doi:10.1145/1017692.1017698

Johnston, D. (1982). Book Reviews: The Soul of a New Machine. Electronics and Power, 193.

Kahneman, D., Slovic, P., \& Tversky, A. (Eds.). (1982). Judgment under Uncertainty: Heuristics and Biases. Cambridge: Cambridge University Press. doi:10.1017/CBO9780511809477

Kidder, T. (1981). Computer design: The Microkids and the Hardy Boys: An inside look at how a maverick team from Data General 'rescued' the company by designing a competitive 32-bit superminicomputer in record time. IEEE Spectrum, 19(9), 48-55. doi:10.1109/MSPEC.1981.6369813

Kidder, T. (1994). Facts and the nonfiction writer. Writer, 107(2), 14.

Latour, B. (1987). Science. In Action: How To Follow Scientists And Engineers Through Society. Cambridge, MA: Harvard University Press.

Lave, J., \& Wenger, É. (1991). Situated Learning: Legitimate Peripheral Participation. Cambridge: Cambridge University Press. doi:10.1017/CBO9780511815355

Lehman, D. W. (1997). Matters of Fact: Reading Nonfiction Over the Edge. Columbus: Ohio State University Press.

Levy, S. (2008). The Soul of a New Machine. IEEE Spectrum, 45(7), 46.

Lueck, T. (1982). Data General: Troubled 'Soul'. The New York Times.

MacKenzie, D. A., \& Wajcman, J. (Eds.). (1999). The Social Shaping of Technology (2nd ed.). Buckingham: Open University Press.

Marx, L., \& Smith, M. R. (1994). Introduction. In M. R. Smith \& L. Marx (Eds.), Does Technology Drive History?: The Dilemma of Technological Determinism. Cambridge: MIT Press.

McLaughlin, F., \& Kidder, T. (1982). The Soul of a New Machine by Tracy Kidder. English Journal, 71(8), 61-62. doi: $10.2307 / 816452$

Meadow, C. (1982). Book Reviews: The Soul of a New Machine. Journal of the American Society for Information Science, 33(5), 349-350. doi:10.1002/asi.4630330520

Mlodinow, L. (2008). The Drunkard's Walk: How Randomness Rules Our Lives. New York: Pantheon Books.

Moon, S. (2004). Tracy Kidder, 'The Soul of a New Machine'. Technology and Culture, 45(3), 597-602. doi:10.1353/tech.2004.0144

Nohria, N. (2013). Envy And the American Dream. Harvard Business Review, 91(1), 142-143.

Nonaka, I., \& Takeuchi, H. (1995). The Knowledge-Creating Company: How Japanese Companies Create The Dynamics of Innovation. New York: Oxford University Press.

Panofsky, E. (1955). Meaning in the Visual Arts. New York: Anchor Books.

Pascale, R. T., \& Athos, A. G. (1981). The Art of Japanese Management: Applications for American Executives. New York: Simon \& Schuster.

Peters, L. H. (2002). Soulful ramblings: An interview with Tracy Kidder. The Academy of Management Executive, 16(4), 45-52. doi:10.5465/AME.2002.8951322 
Pinch, T. J., \& Bijker, W. E. (1987). The Social Construction of Facts and Artifacts: Or How the Sociology of Science and The Sociology of Technology Might Benefit Each Other. In W. Bijker, T. Hughes, \& T. Pinch (Eds.), The Social Construction of Technological Systems: New Directions In The Sociology and History of Technology (pp. 17-50). Cambridge, MA: MIT Press.

Price, G. (2010). The Soul of a New Machine. Retrieved from http://price.mit.edu/blog/2010/01/soul-of-a-newmachine/

Reich, R. B. (1987). Entrepreneurship reconsidered: The team as a hero. Harvard Business Review, 65(3), 77-83.

Ricoeur, P. (1984). Time and Narrative (Vol. 1). (K. McLaughlin \& D. Pellauer, Trans.). Chicago: University of Chicago Press.

Robins, K., \& Webster, F. (1999). Times of The Technoculture: From The Information Society To The Virtual Life. London: Routledge.

Rorty, R. (1992). The pragmatist's progress. In S. Collini (Ed.), Interpretation and Overinterpretation (pp. 89-108). Cambridge: Cambridge University Press.

Schiffrin, D., De Fina, A., \& Nylund, A. (Eds.). (2010). Telling Stories: Language, Narrative, and Social Life. Washington, DC: Georgetown University Press.

Senge, P. M. (1990). The Fifth Discipline: The Art \& Practice of the Learning Organisation. London: Random House.

Shipp, S. (2002). Soul; A book for "a few dozen computer scientists. The Academy of Management Executive, 16(4), 64-68. doi:10.5465/AME.2002.8951327

Silk, L. (1983). Economic Scene; Threats to U.S. In Technology. The New York Times.

Szabo, C. (2013). Homo Fabulans (Storymaker). Retrieved from http://colleenszabo.com/PDF/Homo-Fabulans. pdf

The Associated Press. (1981, August 28). Writer Describes Process of Creating a Computer (AM cycle ed.).

The Globe and Mail. (1982, September 11). TRENDS The New Hero: a butcher, baker or candlestick maker?

Tromer, E. (1997). Tracy Kidder: The Soul of a New Machine. Retrieved from http://www.cs.tau.ac.il/ tromer/ shelf/soul-machine.html

Turner, J. R. (2009). The Handbook of Project Based Management: Leading Strategic Change in Organisations (3rd ed.). New York: McGraw Hill.

United Press Int. (1987). Tracy Kidder goes back to school for next book. U.P.I. July 14, PM Cycle edition. LexisNexis.

Ward, M. (1984). Eagle Takes Off: The Soul of a New Machine. Computer Aided Design, $16(2), 114$. doi:10.1016/0010-4485(84)90241-0

Watson, T. J. (2004). HRM and Critical Social Science Analysis. Journal of Management Studies, 41(3), $447-467$. doi:10.1111/j.1467-6486.2004.00440.x

Whitley, P. (1999). American Cultural History: 1980-1989. Retrieved from http://kclibrary.lonestar.edu/decade80. html

Willet, P. (1983). Tracy Kidder: The Soul of a New Machine. Social Science Information Studies, 3(2), $127-128$. doi:10.1016/0143-6236(83)90040-6 
Lebene Richmond Soga is a PhD candidate in management in the subject areas of leadership, organisations, and behaviour. He holds a Master of Science in Project management and a Master of Research in Information Technology, Management and Organisational Change from Lancaster University, UK. For his PhD, he is investigating the role Web 2.0 technologies play in shaping evolving leadership practices within a Fortune-500 organisation. Lebene seeks an understanding into how various leadership practices emerge with this new technological entrant. He deploys practice theories, especially the actor-network theory in his work. His general research interests cover social technologies in organisations, leadership, project management, and entrepreneurship and he teaches in these areas. He is a member of the Henley Centre for Engaging Leadership at the Henley Business School, University of Reading, United Kingdom. 